\title{
Effect of Education and Training, Career Development and Job Satisfaction of Employee Performance at the Department of Education Office of Gowa
}

\author{
Nur Wahyuni \\ Moeslim Indonesian University, Makassar, Indonesia \\ nur.wahyuni1964@yahoo.com
}

\begin{abstract}
The goal of this research is to analyze the influence of education and training, career development and job satisfaction on the performance of employees at the Department of Education Office of Gowa. The analytical method used in this research is the method of multiple regression analysis. The data used in this study was obtained from the Office of Education employees Gowa the study sample. This research approach is Associative approach. The results showed that: 1) employee performance is closely linked to education and training because it can improve the performance of an employee, both in the handling of existing jobs at the moment and jobs that exist in the future in accordance with tasks in the waistband of the organization, 2) employee performance is closely linked to the career development of an employee, the employee who has a high chance of improving his career will stimulate the motivation to work better in order organizational goals, and 3) employee performance is closely linked to employee satisfaction, an employee with the level high job satisfaction showed a positive attitude towards the work itself, whereas if a person who is not satisfied with his work showed a negative attitude towards work.
\end{abstract}

Keywords: Education and Training, Career Development, Job Satisfaction and Employee Performance

\section{Introduction}

Employee performance is the result of the implementation of the work accomplished by an employee in performing the tasks assigned to him and based on skills, experience and seriousness of time which can be measured by considering the quantity, quality, and timeliness (Trisnaningsih, 2007). The aim of this study is to analyze the effect education \& training, career development and job satisfaction on the performance of employees. Education and training can improve an employee's performance, both in handling jobs that exist at present and existing jobs in the future in accordance with the waistband tasks within the organization (Simbolon, 2008). In line with the development of an organization it is necessary efforts to improve the skills and professionalism of employees by giving attention and coaching are ultimately expected to develop the career path (Harlie, 2011). Career development is the process of improving the ability of individual work achieved in order to achieve the desired career (Rival, 2009). Each employee must be able to increase his career; then the employee should strive to manage themselves, not surrender to fate and not also play with collusion and nepotism.

Job satisfaction in an organization can be judged by how well a person's performance in the organization. The performance of employees affected by the job satisfaction of the employees themselves to their work, which includes: salaries, against a supervisor, work environment, relationship with coworkers, and the work itself. Marihot (2007) stated that job satisfaction indicates the extent to which individuals feel positively or negatively various factors of the tasks in the job. Each individual has a level of satisfaction varies according to the value system that applies to him. The more aspects of the work in accordance with the wishes and aspects of the individual, then there is a tendency of the higher level of work satisfaction. Civil Servant (PNS) in the Office of Education Gowa is a key element of Human Resources (HR) State Apparatus has a role in determining the success of governance and development. Based on observations of researchers at the Office of Education Gowa stated that today the performance of employees in the Office of Education Gowa was already quite good, it is identified that each employee has a motivation as expected, but acknowledged that the competence necessary to be increased again, Based on the background that has been presented, the formulation of the problem in this study is: what education and training, career development and job satisfaction affect the performance of employees at the Department of Education Office of Gowa? 


\section{Literature Review}

Employee Performance: Achievement of organizational goals is only possible due to the efforts of the perpetrators contained in the organization of the institution. Mangkunagara (2009) described that performance is the result of the quality and quantity of work achieved by an employee in performing their duties in accordance with the responsibilities given to him. Rival (2009) indicated that performance of a real behavior displayed by everyone as the resulting performance by employees in accordance with its role within the company. The good performance is a reflection of good behavior so that with a good performance will produce good productivity that will be able to achieve organizational goals (Wulandari, 2010). Sedarmayanti (2006) describes the performance is the result of work that can be accomplished person or group of people within an organization in accordance with the authority and responsibilities of each in achieving the objectives in question organization legally, do not violate the law and morally. Achievements in accordance with the applicable rules and established by the organization.

Education and training: Education and training according to Notoadmodjo (2003) is an effort to develop human resources, particularly to develop intellectual abilities and personality. According to article 1 , the Government Regulation Number 101 of 2000 stated that education and training is the process of organizing learning in order to improve the ability of civil servants to carry out his post. Education and training of civil servants is a process of increasing knowledge, theories related to the work and skills of a civil servant for the purpose can be achieved with the maximum government. To improve the quality of the performance of civil servants as a public servant and the nation needs to be done Education and Training (Revida, 2009).

Career Development: Handoko (2006) highlighted that career is all jobs or positions that are handled or held during one's working life. Thus career shows the development of the individual employees in a hierarchy or rank that can be achieved during the period of employment in an organization. Dubrin (Mangkunagara, 2009) defines career development as staffing activities that help employees plan a future career in the company so that the company and the employee can develop themselves to the maximum.

Job Satisfaction: Marihot (2007) suggests that job satisfaction indicates the extent to which individuals feel positively or negatively various factors of the tasks in the job. Job satisfaction is based on six dimensions, namely the salary, the work itself, boss, co-workers, promotion and working environment. Rival (2009) says that job satisfaction is basically something individual. Every individual have the level of satisfaction varies according to the value system that applies to him. Tingggi increasingly perceived assessment of the activities in accordance with the wishes of individuals, then the higher the satisfaction with that desire. Based on the description above, it can be described as a conceptual framework in Figure 1, below:

\section{Figure 1: Conceptual Framework Research}

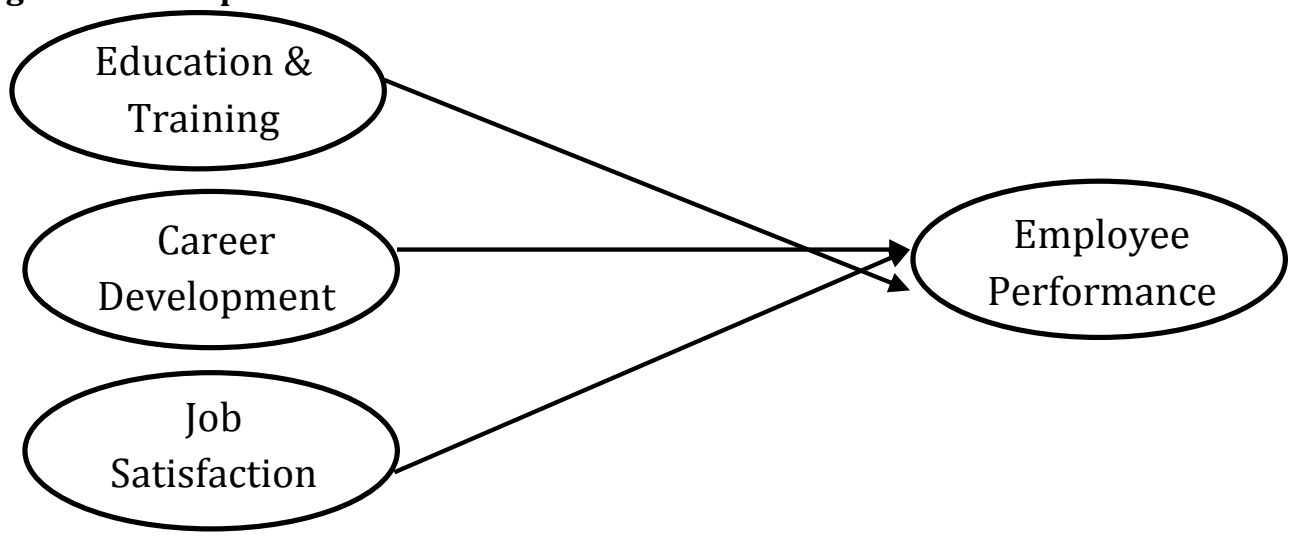




\section{Methodology}

Population and Sample: The population in this study was all employees of the Office of Education Gowa totaling 90 people. The technique used in this research is that all members of the population census are sampled in the study.

Analysis Method: Data analysis methods used in this study is multiple regressions which analyzes the statistics tool is used to determine the influence of the independent variable (X) consists of variable education and training, career development and job satisfaction, the dependent variable $(\mathrm{Y})$ is the performance of employees. Sugiyono (2013), to test the hypothesis in this study used models, namely:

$$
Y=\beta_{0}+\beta 1 X 1+\beta 2 X 2+\beta 3 X 3+e
$$

\section{Where:}

Y

$\mathrm{X} 1$

$\mathrm{X} 2$

$\mathrm{X} 3$

$\beta 0$

$\beta 1-\beta 3$

$\mathrm{e}$
$=$ Performance Officer

=Education and Training

=Career Development

=Job Satisfaction

=Numbers Constants

sion Coefficients

=Error

\section{Results and Discussion}

Simultaneous Analysis: Simultaneous testing (f-test) is performed to determine whether all the independent variables Xi (education and training, career development and job satisfaction) simultaneously have a significant influence on employee performance dependent variable (Y) to the Education Office of Gowa. Implementation of testing carried out based on the following test hypotheses:

$\mathrm{HO} ; \beta \mathrm{i}=0$ againstHa; $\beta \mathrm{i} \neq 0$

With the testing criteria:

If $\mathrm{F}$-account $>\mathrm{F}$-table or $\mathrm{p}$-value $<0,05, \mathrm{H} 0$ is rejected and $\mathrm{Ha}$ accepted

If $\mathrm{F}$-account $<\mathrm{F}$-table or $\mathrm{p}$-value $>0,05, \mathrm{H} 0$ is accepted and Ha rejected

Thus the regression equation can be used to measure whether the independent Xi variables affect the dependent variable Yi.

Table 1: Analysis ANOVA

\begin{tabular}{lllllll}
\hline \multicolumn{2}{l}{ Model } & Sum of Squares & df & $\begin{array}{l}\text { Mean } \\
\text { Square }\end{array}$ & F & Sig. \\
\hline 1 & Regression & 12.616 & 3 & 4.205 & 121.042 & $.000^{\mathrm{a}}$ \\
& Residual & 2.502 & 72 & .035 & & \\
& Total & 15.118 & 75 & & & \\
\hline
\end{tabular}

a. Predictors: (Constant), Job Satisfaction, Education \& Training, Career Development

b. Dependent Variable: Employee Performance

Source: data processed

The table above explains that all the independent variables Xi (education and training, career development and job satisfaction) positive and significant effect on the dependent variable $Y$ (employee performance) with the value of F-test 121.042 and significance level of 0.000 or p-value $<0.05$. Based on the criteria of hypothesis testing, then $\mathrm{HO}$ is rejected and $\mathrm{Ha}$ accepted. This means that simultaneously all independent variables have real differences with 0 . At the same time, regression analysis obtained can be used to make statistical predictions for measuring influence. Effect of simultaneous variable Xi to variable $\mathrm{Y}$ can be seen also from simultaneous determination coefficient (R2). This can be seen from the analysis Simultaneous determination in the following table: 
Table 2: Analysis of Simultaneous Determination Model Summary

\begin{tabular}{|c|c|c|c|c|c|c|c|c|c|}
\hline M & $\mathbf{R}$ & quare & $\begin{array}{l}\text { Adjusted } \\
\text { R } \\
\text { Square }\end{array}$ & $\begin{array}{l}\text { Std. Error } \\
\text { of the } \\
\text { Estimate }\end{array}$ & $\begin{array}{l}\text { Change St } \\
\text { R Square } \\
\text { Change }\end{array}$ & $\begin{array}{l}\text { tatistics } \\
\text { F } \\
\text { Change }\end{array}$ & df1 & df2 & $\begin{array}{l}\text { Sig. F } \\
\text { Change }\end{array}$ \\
\hline 1 & $.914^{\mathrm{a}}$ & .835 & .828 & .18640 & .835 & 121.042 & 3 & 72 & .000 \\
\hline
\end{tabular}

a. Predictors: (Constant), Job Satisfaction, Education \&Training, Career Development

Source: data processed

The correlation coefficient (R) of 0.914 means that there is a positive relationship between the variables Xi and direction with variable $\mathrm{Y}$. value of $\mathrm{R} 2=0.835$. This means, the effect of variable Xi (education and training, career development and job satisfaction) simultaneously to variable $\mathrm{Y}$ (employee performance) was83.5\% and the effect of other variables at $16.5 \%$. This influence is in excellent because it is greater than $60 \%$ and significant ( $p$-value) $=0,000$

Partial analysis (t test): Presentation of the results of the analysis is intended to present the regression equation obtained in the study.

Table 3: Regression Coefficients and Significant Levels Coefficients ${ }^{\mathrm{a}}$

\begin{tabular}{|c|c|c|c|c|c|c|}
\hline \multirow{2}{*}{\multicolumn{2}{|c|}{ Model }} & \multicolumn{2}{|c|}{$\begin{array}{l}\text { Unstandardized } \\
\text { Coefficients }\end{array}$} & \multicolumn{3}{|c|}{$\begin{array}{l}\text { Standardized } \\
\text { Coefficients }\end{array}$} \\
\hline & & B & Std. Error & Beta & $\mathbf{t}$ & Sig. \\
\hline \multirow[t]{4}{*}{1} & (Constant) & .473 & .225 & & 2.099 & .039 \\
\hline & $\begin{array}{l}\text { Education } \\
\text { Training }\end{array}$ & .144 & .060 & .150 & 2.393 & .019 \\
\hline & Career Development & .410 & .106 & .469 & 3.885 & .000 \\
\hline & Job Satisfaction & .329 & .119 & .364 & 2.763 & .007 \\
\hline
\end{tabular}

a. Dependent Variable: Employee

Performance

Source: data processed

Statistical hypothesis test is:

H0; $\beta \mathrm{i}=0$ againstHa; $\beta \mathrm{i} \neq 0$.The significance level $(\alpha)=0.05$

Testing criteria:

If the $\mathrm{t}$-test>t-table, then $\mathrm{H} 0$ is rejected and $\mathrm{Ha}$ accepted with $\alpha=0.05$

If the $\mathrm{t}$-test $<\mathrm{t}$-table, then $\mathrm{H} 0$ is accepted and Ha rejected with $\alpha=0.05$

From the table it appears that partially, all variables have a probability analysis (level of significance) that is different and each variable is explained as follows:

- Variables education and training has a positive and significant impact on the performance of employees at the Department of Education Office of Gowa, based on partial test results using the value $t$, found value $t$ count for the education and training variables of 2.393 with a significance level of $0.019(\mathrm{p}<5 \%)$. The test results concluded that the hypothesis for the variables of education and training that has been proposed is supported by empirical evidence.

- Variable career development has a positive and significant impact on the performance of employees at the Department of Education Office of Gowa, based on partial test results using the value $t$, discovered the value of T-count for career development variables of 3.885 with a significance level of $0.000(\mathrm{p}<5 \%)$, The test results concluded that the hypothesis for the variables of career development that has been proposed is supported by empirical evidence. 
- Variable job satisfaction has a positive and significant impact on the performance of employees at the Department of Education Office of Gowa, based on partial test results using the value $t$, found value $t$ count for the variable job satisfaction at 2.763 with a significance level of 0.007 ( $p>5 \%$ ), The test results concluded that the hypothesis of job satisfaction variables that have been proposed are not supported by empirical evidence.

Thus the hypothesis $\mathrm{HO}$ is rejected and Ha accepted for education and training variables (X1) career development (X2) and job satisfaction (X3). This means, the regression coefficients obtained from the analysis significantly different from 0 at the $95 \%$ confidence level. From the results of the analysis of all the variables that had regression coefficients significantly different from zero, on the basis of these results, the regression equation obtained can be used to make statistical predictions, including forecasting and regression equation obtained is:

$Y=0,473+0,144 X_{1}+0,410 X_{2}+0,329 X_{3}$

The multiple regression equation can be explained as follows:

- The coefficient $\mathrm{b} 0=0.473$ means that if the education and training variables (X1), career development (X2), and job satisfaction (X3) no change (constant), then the employee performance $(\mathrm{Y})$ in the Office of Education Gowa will not change or amounting to 0.473.

- Coefficient $\mathrm{b} 1=0.144$ means that any increase in the education and training variables (X1), it is expected to improve employee performance $(\mathrm{Y})$ to the Education Office of Gowa. Tcount amounted to 2.393 with a significance level of 0.019 (sig <0.05) means that there is a positive and significant influence between education and training (X1) with employee performance (Y), assuming other variables (career development and job satisfaction) unchanged,

- The coefficient b2 $=0.410$ means that any increase career development variables (X2), it is expected to improve employee performance $(\mathrm{Y})$ to the Education Office of Gowa. Tcount amounted to 3.885 with a significance level of 0.000 (sig $<0.05)$ means that there is a positive and significant influence between the variables of career development (X2) with employee performance (Y), assuming other variables (education and training as well as job satisfaction) do not experience change.

- The coefficient b3 $=0.329$ means that any increase job satisfaction variable (X3), it is expected to improve employee performance (Y) to the Education Office of Gowa. Tcount amounted to 2.763 with a significance level of 0.007 (sig> 0.05) means that there is a positive and significant effect between job satisfaction (X3) with employee performance (Y), assuming other variables (education and training and career development)

The influence of each independent variable on the performance of employees at the Department of Education Office of Gowa described as follows:

Effect of Education and Training on Employee Performance: The regression analysis showed that the education and training variables positive and significant impact on the performance of employees at the Department of Education Office of Gowa. This means the employee's performance is closely linked to education and training because it can improve an employee's performance, both in handling jobs that exist at present and existing jobs in the future in accordance with the waistband tasks within the organization. It is evident also from the education and training program that is programmed by the Office of Education Gowa has been right on target. In addition, employees must also be provided with an experience that has a major role in solving the problems and constraints experienced by employees in running the organization to be more efficient and effective in order to achieve organizational goals.

Effect of Career Development for Employee Performance: The regression analysis showed that the variables of career development and significant positive effect on the performance of employees at the Department of Education Office of Gowa. Career development is an approach-approach to activities formally for improvements or repairs, growth, job satisfaction, knowledge and abilities of employees in order to ensure that people who are qualified and experience available when needed, thus planning and development clear and steady career that will help employees and organizations to success. This means the employee's 
performance is closely linked to the development of an employee's career. Employees who have a high chance of improving his career will stimulate the motivation to work better in order pencapian organizational goals. Organizations that have a systematic model in career development of employees will have good performance. The results support the research conducted by Harlie (2011) which states that career development is partially significant effect on employee performance. Each employee can enhance his career; then the employee should strive to manage themselves, not surrender to fate and not also play with collusion and nepotism. So that the effort is not wasted, running in the actual rail, then a career should be planned. Given a good career planning in order to develop careers themselves, the employee will be able to make tactics, what should be done to achieve certain levels. Employees should be trained and developed in specific areas to reduce and eliminate the bad work habits or to learn new skills that will improve their performance.

Effect of Job Satisfaction on Employee Performance: The regression analysis showed that job satisfaction variable positive and significant effect on the performance of employees at the Department of Education Office of Gowa. Job satisfaction is a feeling that the level of positive / negative aspects of the job, the work situation and relations with colleagues. This means the employee's performance is closely linked to employee satisfaction. An employee with a high level of job satisfaction showed a positive attitude towards the work itself, whereas if a person who is not satisfied with his work showed a negative attitude towards the job. This will affect the performance of employees at the Department of Education Office of Gowa. Marihot (2007: 290) suggests that job satisfaction indicates the extent to which individuals feel positively or negatively various factors of the tasks in the job. Job satisfaction is based on six dimensions, namely the salary, the work itself, boss, co-workers, promotion and working environment. Each individual has a level of satisfaction varies according to the value system that applies to him. The more aspects of the work in accordance with the wishes and aspects of the individual, then there is a tendency of the higher level of work satisfaction. When the employee satisfied with the work they will try to do my best to produce a good performance, while conversely a disgruntled employee may also reduce the effort to complete its work.

\section{Conclusion and Recommendations}

Based on the results of research and discussion that has been stated, this research resulted in findings can be summarized as follows: education and training, career development and job satisfaction positive and significant impact on the performance of employees at the Department of Education Office of Gowa and the hypothesis is accepted. Office of Education Gowa also need to conduct job analysis because this analysis is important to know the needs of employees of each section in the Education Office of Gowa, the needs of employees is certainly not only related to the quantity, but also quality of human resources required, if this is done it will give employee satisfaction on what has been achieved.

\section{Reference}

Handoko, H. (2006). The organization, Amara Books, Yogyakarta.

Harlie, M. (2011). Effects of Work Discipline, Motivation and Career Development to Performance in Government Tabalong civil servants in Tanjung South Kalimantan. Application Management Journal, 10(4). STIA Tabalong South Kalimantan.

Mangkunagara. (2009). Performance Evaluation Resources Manusia. Publisher: Rafika Aditama. Bandung.

Marihot, E. (2007). Human Resource Management (fourth printing). Publisher: Grasindo. Jakarta.

Notoadmojo, S. (2003). Education and Health Behavior. Rineka Reserved. Jakarta.

Regulation of the Minister of the Interior 31 of 2007 on Guidelines for the Implementation of Education and Training in the Ministry of the Interior and Local Government Regulation (PP) No. 101 of 2000 on Education and Job Training for Civil Servants Regulation of the State Administration Institution No. 13 Year 2011 on Guidelines for the Development of Education Implementation and Technical Training.

Revida. (2009). Management Education and Training System. Access: 10- 01-2011. http://blogspot.com/2009/.html)

Rival, V. (2009). Human Resource Management for Companies from Theory to Practice. Issue 2. RajaGrafindo. Jakarta. 
Sedarmayanti. (2006). Human Resource Management. Issue 1 Publisher: PT. Refika Aditama. Bandung.

Simbolon Pormadi. 2008. Efforts to Improve the Performance of civil servants. Access 18-01-2011. http://blogspot.com/2008/06/.html).

Sugiyono. (2013). Business Research Methods (Approach Quantitative, Qualitative, and R \& D). Publisher: Alfabeta. Bandung.

Trisnaningsih, S. (2007). Independence and Mediating Effects of Organizational Commitment As understanding of Good Governance Leadership Style and Organizational Culture Performance Against. National Symposium Accounting X.Law of the Republic of Indonesia No. 20 of 2003 on National Education System.

Wulandari, A. (2010). Effect of Training and Work Discipline for Employee Performance Education Foundation Telkom. http://www.ekuitas.ac.id 